\title{
STUDIES ON MEIOTIC CHROMOSOMES IN INFERTILE MEN AND CONTROLS WITH NORMAL KARYOTYPES
}

\author{
N. E. SKAKKEBÆK, JEAN I. BRYANT AND J. PHILIP \\ The Chromosome Laboratory, Department of Obstetrics and Gynecology, Rigshospitalet, \\ University of Copenhagen, Denmark, and Division of Medical Genetics, \\ Department of Medicine, University of Washington, \\ Seattle, Washington, U.S.A.
}

(Received 30th August 1972)

\begin{abstract}
Summary. The meiotic chromosomes in diakinesis-metaphase I (MI) and metaphase II (MII) of eighteen controls and seventy-four infertile men with a normal 46,XY chromosome complement were investigated. The MII/MI ratio was decreased in the infertile group. The difference in mean chiasma frequency between the two groups was not statistically significant, but there was a significant variation between individuals. In three infertile men, a small proportion of cells in MI contained indistinct, grossly fragmented chromosomes with low chiasma frequency. The non-pairing of sex chromosomes and homologous autosomes in MI was the same in the controls and infertile men. One hundred and seventy-four cells $(15 \%)$ of 1159 cells contained non-paired sex chromosomes and in six cells $(0.5 \%)$, two small homologous chromosomes were separated. Non-pairing may give rise to zygotes with abnormal chromosome complements. The relative number of polyploid cells in MII, but not in spermatogonial metaphase and MI, was significantly increased in the infertile men. No structural abnormalities were detected.
\end{abstract}

\section{INTRODUGTION}

Studies of meiotic chromosomes in men with normal karyotypes may provide knowledge about the occurrence of structural and numerical chromosome abnormalities, abnormal chiasma formation, non-pairing of homologous chromosomes and polyploidy. Such investigations may also be supplementary to the histological analysis in the diagnosis of testicular defects in infertile men. Few studies on meiotic chromosomes of groups of these men have been reported (Kjessler, 1966; McIlree, Price, Court Brown, Tulloch, Newsam \& Maclean, 1966; Luciani, 1970a, b).

We here report and compare the results from a study of meiotic chromosomes in eighteen controls and seventy-four infertile men with normal karyotypes. 


\section{MATERIALS AND METHODS}

\section{Controls}

Testicular material was obtained from twenty-one volunteers, aged 19 to 39 years, with normal 46,XY chromosomes in lymphocytes (Table 1). Semen specimens were examined before biopsy, except in one case, and all candidates who fulfilled the following spermiogram criteria were included in the investigation: sperm count $>60 \times 10^{6} / \mathrm{ml}$, good motility and $<50 \%$ morphologically abnormal cells. None of the subjects had a history of involuntary childlessness and several had produced offspring. Further data on the subjects were given

Table 1. Chromosome count distribution in the volunteer group of control males

\begin{tabular}{c|ccccc|c}
\hline Case & \multicolumn{5}{|c|}{ No. of cells showing } & \\
no. & $<45$ & 45 & 46 & 47 & $>47$ & \\
\hline 1 & & & 30 & & & \\
2 & & & 30 & & & 30 \\
3 & & & 29 & 1 & & 30 \\
4 & & & 29 & & 1 & 30 \\
5 & & 1 & 29 & & & 30 \\
6 & & & 30 & & & 30 \\
7 & & & 30 & & & 30 \\
8 & & & 14 & 1 & & 15 \\
9 & & 1 & 15 & & & 15 \\
10 & & 2 & 14 & & & 15 \\
11 & & & & & & 16 \\
12 & & & 15 & & & 15 \\
13 & 1 & & 13 & & 1 & 15 \\
14 & & & 15 & & & 15 \\
15 & & 1 & 14 & & & 15 \\
16 & & 1 & 14 & & & 30 \\
17 & & 2 & 28 & & & \\
18 & & & & & \\
& & & & & \\
\hline
\end{tabular}

* The chromosome analysis was unsuccessful and an additional blood specimen could not be obtained.

previously and the histology of the seminiferous epithelium, which was considered normal, was described quantitatively (Skakkebæk \& Heller, 1973). Successful preparations were obtained from seventeen of the twenty-one subjects. In addition, a 37-year-old man (Case 18) who fulfilled the same criteria was investigated.

\section{Infertile men}

Seventy-four men, aged 23 to 51 years (average 31.6 years) were investigated. All had normal chromosome complements in lymphocytes, examined by conventional techniques. In general, the chromosomal analysis was carried out on thirty cells or more. In some cases, only ten or twenty cells were examined. No evidence of mocaicism was found (Philip, Skakkebæk, Hammen, Johnsen \& Rebbe, 1970). The patients were found in a group of ninety-three men referred for testicular biopsy at the fertility clinic due to aspermia, 'severely impaired fertility' or 'very severely impaired fertility' according to our usual classification of the spermiograms (Hammen, 1944). At least three semen specimens were 
analysed, except in cases where semen analyses had been carried out in other laboratories with similar results. In such cases, only one or two were done. All patients had severe deficiencies in the three main criteria of semen quality (number, motility and morphology). In the majority, all of these parameters were abnormal. The average sperm count of each patient is recorded in Table 5 .

Six of the original group of ninety-three patients had abnormal karyotypes (Philip et al., 1970) and these patients will not be considered in the present report. The preparations from thirteen patients did not contain cells in meiosis. This was due either to germ cell aplasia or to unsuccessful preparation. The remaining seventy-four patients constitute the material.

\section{Procedure}

Unilateral testicular biopsies, approximately 2 to $4 \mathrm{~mm}$ in diameter, were removed under local anaesthesia. Generally, biopsies were taken from the right testis. In some cases (e.g. failure of descent of the right testis or previous biopsy on the right side), biopsies were taken from the left. In one patient (Case 73), bilateral biopsies were examined. Meiotic preparations were made according to a modification of the method of Evans, Breckon \& Ford (1964). Orcein stain (G. T. Gurr) was used. A differential count of cells in spermatogonial metaphase, diakinesis-metaphase I (MI) and metaphase II (MII) was determined by scanning 100 of these cell types on one or more slides (in eleven cases, less than 100 cells were found). Polyploid cells were included in the counts, although they were recorded separately. Diploid cells in MII were recorded as

Table 2. Distribution of cells in spermatogonial metaphase (SM), diakinesis (MI) and metaphase II (MII) in the volunteer group of control males

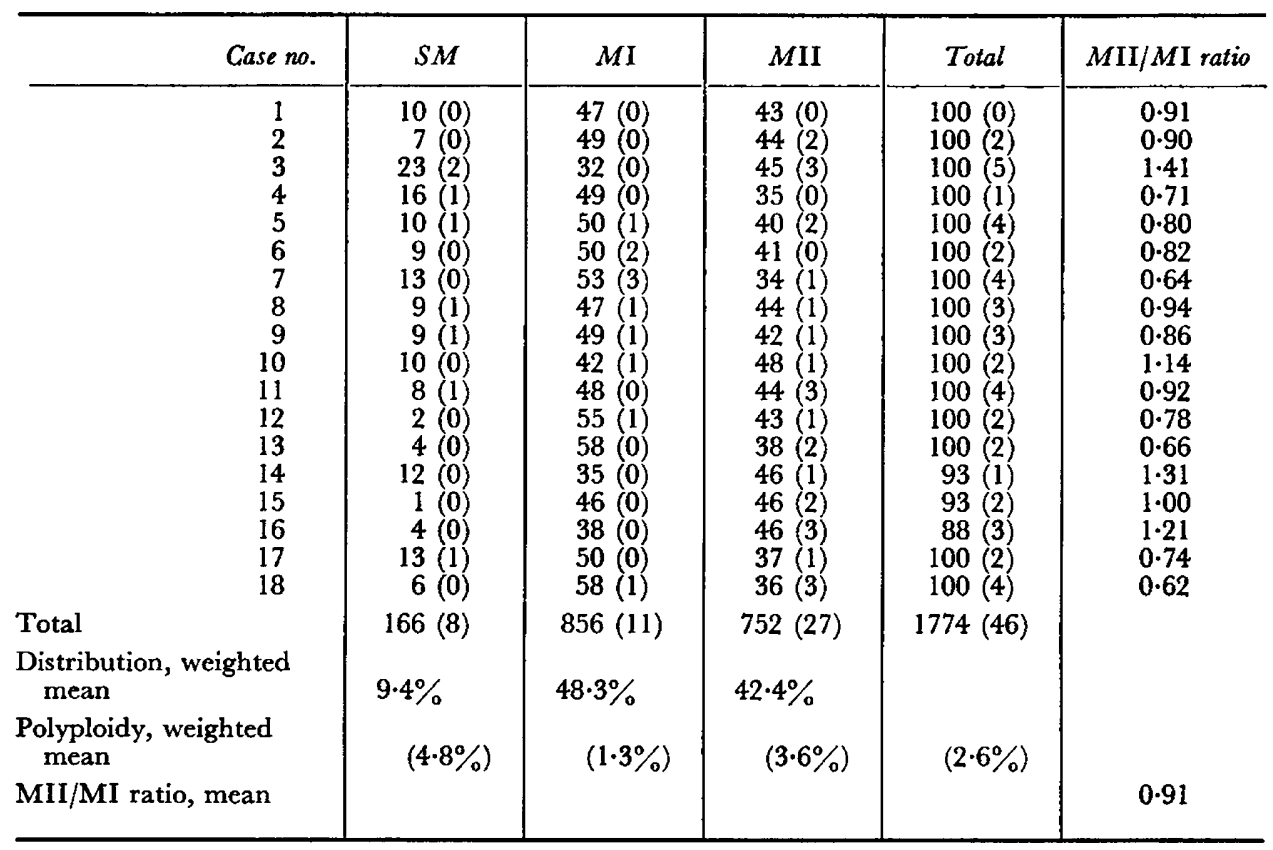

Figures in parentheses $=$ nos of polyploid cells included in the counts. 
polyploid. A detailed analysis could be performed on a varying number of suitable cells in diakinesis from each individual. Results from those cases where ten or more such cells were found were recorded. In these, the numbers of bivalents and univalents were determined. The sex chromosomes were recorded separately. The autosomal chiasma number of cells in diakinesis was determined in the clearest cells from six of the fertile and sixteen of the infertile men. Only counts from patients where three or more cells could be analysed are included. All microscope studies were made by the first author.

Table 3. Analysis of selected cells in diakinesis-metaphase I in testicular biopsies from control and infertile males

\begin{tabular}{|c|c|c|c|c|c|c|c|c|}
\hline \multirow{3}{*}{$\begin{array}{l}\text { Case } \\
\text { no. }\end{array}$} & \multicolumn{5}{|c|}{ No. of cells showing* } & \multirow{3}{*}{$\begin{array}{c}\text { Total } \\
\text { analysed }\end{array}$} & \multicolumn{2}{|c|}{$\begin{array}{l}X \text { and } Y \\
\text { separated }\end{array}$} \\
\hline & \multirow[t]{2}{*}{$23, X r$} & \multirow[t]{2}{*}{$24, X, Y$} & \multirow[t]{2}{*}{$22, X Y$} & \multirow[t]{2}{*}{$\leqslant 21, X Y$} & \multirow[t]{2}{*}{ Other aberrations } & & & \\
\hline & & & & & & & Total & $\%$ \\
\hline $\begin{array}{c}\text { Controls } \\
1 \\
2\end{array}$ & $\begin{array}{r}38 \\
104\end{array}$ & $\begin{array}{r}4 \\
21\end{array}$ & $\begin{array}{l}2 \\
4\end{array}$ & $\begin{array}{l}0 \\
1\end{array}$ & $\begin{array}{l}\quad 0 \\
3 \text { cells: } \\
24, X Y,+I: I(S A)\end{array}$ & $\begin{array}{r}44 \\
133\end{array}$ & $\begin{array}{r}4 \\
21\end{array}$ & $\begin{array}{r}9 \cdot 1 \\
15 \cdot 8\end{array}$ \\
\hline $\begin{array}{l}3 \\
4\end{array}$ & $\begin{array}{r}122 \\
22\end{array}$ & $\begin{array}{r}19 \\
4\end{array}$ & $\begin{array}{l}2 \\
0\end{array}$ & $\begin{array}{l}4 \\
0\end{array}$ & $\begin{array}{l}\text { cell: low } \\
\text { chiasma frequency }\end{array}$ & $\begin{array}{r}147 \\
27\end{array}$ & $\begin{array}{r}19 \\
4\end{array}$ & $\begin{array}{l}12 \cdot 9 \\
14 \cdot 8\end{array}$ \\
\hline 6 & 64 & 13 & 1 & 2 & 1 cell: $22, X, Y$ & 81 & 14 & $17 \cdot 3$ \\
\hline 8 & 10 & 0 & 0 & 0 & 0 & 10 & 0 & 0.0 \\
\hline 10 & 9 & 2 & 0 & 0 & 0 & 11 & 2 & 18.2 \\
\hline 18 & 25 & 10 & 1 & 3 & 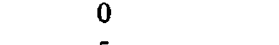 & 39 & 10 & $25 \cdot 6$ \\
\hline Total & 394 & 73 & 10 & 10 & 5 & 492 & 74 & $15 \cdot 0$ \\
\hline \multirow{2}{*}{$\begin{array}{c}\text { Infertile } \\
\text { men } \\
24\end{array}$} & & & & & \multirow{22}{*}{$\begin{array}{c}1 \text { cell: } \\
24, X Y,+I: I(S A) \\
0 \\
0 \\
1 \text { cell: } 24, X Y \\
0 \\
0 \\
0 \\
0 \\
0 \\
0 \\
0 \\
1 \text { cell: } \\
24, X Y,+I: I(S A) \\
0 \\
0 \\
0 \\
0 \\
1 \text { cell: } 21, X, Y \\
0 \\
1 \text { cell: } \\
24, X Y,+I: I(S A) \\
1 \text { cell: } 23, X Y,+ \text { mar } \\
0 \\
0\end{array}$} & & & \\
\hline & 30 & 8 & 4 & 1 & & 44 & 8 & $18 \cdot 2$ \\
\hline 27 & 13 & 1 & 0 & 1 & & 15 & 1 & $6 \cdot 7$ \\
\hline 29 & 31 & 3 & 3 & 0 & & 37 & 3 & $8 \cdot 1$ \\
\hline 32 & 54 & 9 & 2 & 0 & & 66 & 9 & $13 \cdot 6$ \\
\hline 33 & 15 & 4 & 0 & 2 & & 21 & 4 & $19 \cdot 0$ \\
\hline 44 & 8 & 5 & 0 & 0 & & 13 & 5 & $38 \cdot 5$ \\
\hline 45 & 30 & 3 & 1 & 2 & & 36 & 3 & $8 \cdot 3$ \\
\hline 50 & 47 & 8 & 2 & 3 & & 60 & 8 & $13 \cdot 3$ \\
\hline 51 & 22 & 2 & 1 & 0 & & 25 & 2 & $8 \cdot 0$ \\
\hline 52 & 16 & 4 & 0 & 2 & & 22 & 4 & $18 \cdot 2$ \\
\hline 55 & 14 & 2 & 1 & 2 & & 19 & 2 & $10 \cdot 5$ \\
\hline 57 & 8 & 4 & 0 & $i$ & & 14 & 4 & $28 \cdot 6$ \\
\hline 58 & 27 & 8 & 1 & 1 & & 37 & 8 & $21 \cdot 6$ \\
\hline 59 & 22 & 2 & 2 & 0 & & 26 & 2 & $7 \cdot 7$ \\
\hline 60 & 28 & 2 & 0 & 1 & & 31 & 2 & $6 \cdot 5$ \\
\hline 65 & 26 & 8 & 0 & 0 & & 34 & 8 & 23.5 \\
\hline 66 & 14 & 2 & 0 & 0 & & 17 & 3 & $17 \cdot 6$ \\
\hline 70 & 8 & $\overrightarrow{1}$ & 0 & 2 & & 11 & 1 & $9 \cdot 1$ \\
\hline $73 \mathrm{R}$ & 29 & 6 & 2 & 1 & & 39 & 6 & $15 \cdot 4$ \\
\hline & & 2 & 1 & 1 & & 29 & 2 & 6.9 \\
\hline & 47 & 14 & 0 & 0 & & 61 & 14 & $23 \cdot 0$ \\
\hline Total & 522 & 99 & 20 & 20 & 6 & 667 & 100 & 15.0 \\
\hline & & & & & & & & \\
\hline
\end{tabular}

$\mathrm{R}=$ right $; \mathrm{L}=$ left $; \mathrm{mar}=$ marker chromosome. Nomenclature according to 4 th Int. Conf. on Standardization in Human Cytogenetics (1971).

* +I:I(SA)-two small autosomes separated. XY-sex chromosomes appear as bivalent. X,Y-sex chromosomes appear as univalents. 
RESULTS

Controls

The distribution of cells in spermatogonial metaphase (Pl. 1, Fig. 1), MI (Pl. 1, Fig. 2) and MII (Pl. 2, Fig. 3) are presented in Table 2. The relative number of cells in spermatogonial metaphase was low. The mean ratio between MII and MI was 0.9 with a range between 0.6 and 1.4 . Polyploid cells were found in $4.8 \%$ of cells in spermatogonial metaphase, $1.3 \%$ of cells in MI and $3.6 \%$ of cells in MII (PI. 2, Fig. 4).

Table 4. Chiasma analysis in testicular biopsies from control and infertile males

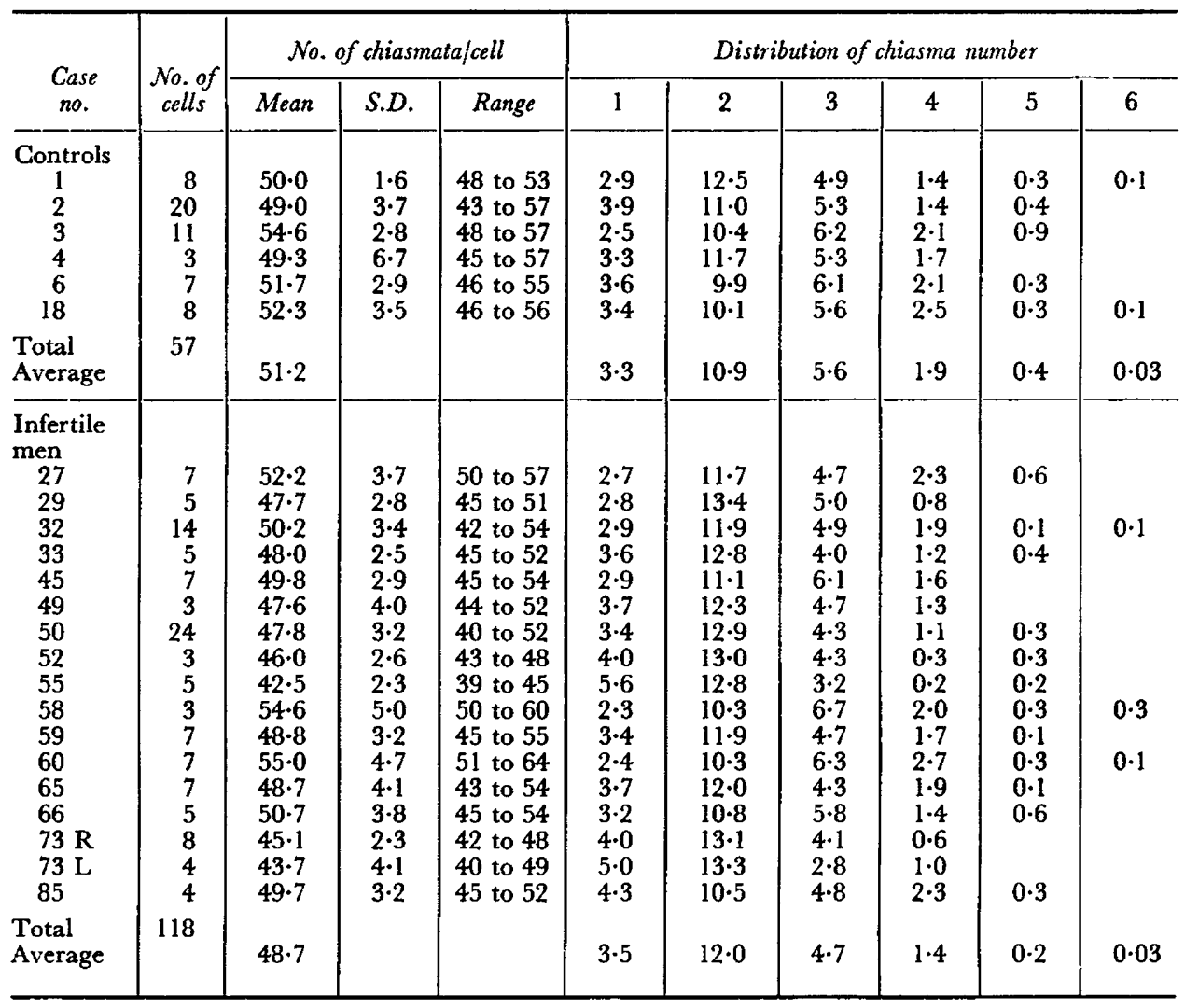

$\mathbf{R}=$ right $\mathbf{L}=$ left.

A total of 492 cells in diakinesis from eight individuals was analysed in detail with the results shown in Table 3 . A total of twenty-one cells $(4.3 \%)$ lacked one or more bivalents (Pl. 3, Fig.5). The sex chromosomes were separated in $15.0 \%$ of all cells (Pl. 3, Fig. 6), although a variation between 0 and $25.6 \%$ was found. A pair of the smallest autosomes were separated in three cells from one patient.

The average autosomal chiasma frequency for the group studied was $51 \cdot 2$ (Table 4). The lowest frequency was found in Case 2, with an average of 49.0, and the highest was found in Case 3 , with a mean of 54.6. A single cell with a 
very low chiasma frequency in Case 4 was considered abnormal (Pl. 4, Fig. 7) and it is not included in the figures of Table 4.

\section{Infertile men}

The distribution of cells in spermatogonial metaphase, MI and MII is shown in Table 5. The MII/MI ratio varied considerably, with a mean of 0.5 and a range from 0.0 to 1.4 , although only three individuals exceeded 1.0 .

Table 5. Sperm counts and distribution of cells in spermatogonial metaphase (SM), diakinesis (MI) and metaphase II (MII) in testicular biopsies from infertile males

\begin{tabular}{|c|c|c|c|c|c|c|}
\hline Case no. & $\begin{array}{c}\text { Av. sperm } \\
\text { count } \\
\left(10^{6} / \mathrm{ml}\right)\end{array}$ & $S M$ & $M I$ & $M \mathrm{II}$ & Total & $M \mathrm{II} / M \mathrm{I}$ ratio \\
\hline $\begin{array}{r}19 \\
20 \\
21 \\
22 \\
23 \\
24 \\
* 25 \\
26 \\
27 \\
28 \\
29 \\
30 \\
31 \\
32 \\
33 \\
34 \\
35 \\
36 \\
37 \\
38 \\
39 \\
40 \\
41 \\
42 \\
43 \\
44 \\
45 \\
46 \\
47 \\
48 \\
49 \\
50 \\
51 \\
52 \\
53 \\
* 54 \\
* 55 \\
* 56 \\
57 \\
58 \\
59 \\
* 60 \\
* 61 \\
62 \\
63 \\
* 64 \\
65 \\
66 \\
* 67\end{array}$ & $\begin{array}{c}0 \\
12 \cdot 5 \\
17 \cdot 5 \\
0 \cdot 4 \\
0 \\
13 \cdot 5 \\
1 \cdot 3 \\
1 \cdot 3 \\
4 \cdot 4 \\
0 \cdot 1 \\
14 \cdot 0 \\
14 \cdot 3 \\
16 \cdot 5 \\
16 \cdot 5 \\
12 \cdot 1 \\
35 \cdot 0 \\
0 \cdot 17 \\
1 \cdot 77 \\
17 \cdot 2 \\
5 \cdot 7 \\
0 \cdot 4 \\
6 \cdot 4 \\
0 \\
17 \cdot 6 \\
0 \\
6 \cdot 3 \\
33 \cdot 0 \\
24 \cdot 3 \\
3 \cdot 1 \\
0 \cdot 5 \\
2 \cdot 4 \\
18 \cdot 7 \\
91 \cdot 3 \\
21 \cdot 6 \\
0 \cdot 4 \\
2 \cdot 8 \\
14 \cdot 0 \\
10 \cdot 0 \\
2 \cdot 7 \\
0 \\
0 \\
10 \cdot 1 \\
21 \cdot 0 \\
5 \cdot 6 \\
0 \cdot 6 \\
18 \cdot 3 \\
2 \cdot 2 \\
27 \cdot 5 \\
0 \cdot 6\end{array}$ & $\begin{array}{r}14(0) \\
13(1) \\
37(4) \\
44(5) \\
26(1) \\
7(1) \\
9(0) \\
18(0) \\
27(2) \\
9(0) \\
8(1) \\
8(0) \\
22(0) \\
1(0) \\
7(0) \\
26(0) \\
14(0) \\
29(2) \\
11(0) \\
7(1) \\
17(0) \\
64(1) \\
53(6) \\
9(0) \\
24(2) \\
15(1) \\
21(1) \\
19(0) \\
17(1) \\
20(2) \\
61(3) \\
4(0) \\
19(0) \\
14(1) \\
5(1) \\
37(1) \\
34(4) \\
12(1) \\
20(0) \\
7(0) \\
53(5) \\
11(1) \\
39(0) \\
38(0) \\
45(1) \\
22(1) \\
10(1) \\
36(1) \\
52(5)\end{array}$ & $\begin{array}{l}10(0) \\
46(1) \\
34(0) \\
53(0) \\
33(1) \\
68(0) \\
17(1) \\
62(1) \\
44(0) \\
15(0) \\
71(1) \\
47(0) \\
63(1) \\
59(0) \\
56(1) \\
41(2) \\
35(1) \\
40(0) \\
65(3) \\
59(0) \\
75(1) \\
25(0) \\
34(2) \\
63(1) \\
51(1) \\
61(0) \\
40(0) \\
51(1) \\
57(4) \\
72(0) \\
25(1) \\
63(1) \\
52(0) \\
54(1) \\
66(0) \\
34(0) \\
54(0) \\
63(1) \\
57(2) \\
50(3) \\
47(0) \\
63(0) \\
44(1) \\
52(0) \\
47(0) \\
59(0) \\
50(0) \\
46(0) \\
38(1)\end{array}$ & $\begin{array}{r}1(0) \\
18(7) \\
29(6) \\
3(1) \\
41(8) \\
25(1) \\
5(1) \\
20(1) \\
29(0) \\
6(0) \\
21(5) \\
13(1) \\
15(3) \\
40(3) \\
37(3) \\
33(5) \\
11(1) \\
31(9) \\
24(0) \\
34(3) \\
8(0) \\
11(3) \\
13(3) \\
28(1) \\
25(1) \\
24(3) \\
39(9) \\
30(0) \\
26(6) \\
3(1) \\
14(5) \\
33(3) \\
29(3) \\
32(4) \\
29(1) \\
29(3) \\
12(3) \\
25(3) \\
23(0) \\
43(4) \\
0 \\
26(4) \\
17(1) \\
10(2) \\
8(1) \\
19(3) \\
40(0) \\
18(2) \\
10(0)\end{array}$ & $\begin{array}{c}25(0) \\
77(9) \\
100(10) \\
100(6) \\
100(10) \\
100(2) \\
31(2) \\
100(2) \\
100(2) \\
30(0) \\
100(7) \\
68(1) \\
100(4) \\
100(3) \\
100(4) \\
100(7) \\
60(2) \\
100(11) \\
100(3) \\
100(4) \\
100(1) \\
100(4) \\
100(11) \\
100(2) \\
100(4) \\
100(4) \\
100(10) \\
100(1) \\
100(11) \\
95(3) \\
100(9) \\
100(4) \\
100(3) \\
100(6) \\
100(2) \\
100(4) \\
100(7) \\
100(5) \\
100(2) \\
100(7) \\
100(5) \\
100(5) \\
100(2) \\
100(2) \\
100(2) \\
100(4) \\
100(1) \\
100(3) \\
100(6)\end{array}$ & $\begin{array}{l}0.10 \\
0.39 \\
0.85 \\
0.06 \\
1.24 \\
0.37 \\
0.29 \\
0.32 \\
0.66 \\
0.40 \\
0.30 \\
0.28 \\
0.24 \\
0.68 \\
0.66 \\
0.80 \\
0.31 \\
0.78 \\
0.37 \\
0.58 \\
0.11 \\
0.44 \\
0.38 \\
0.44 \\
0.49 \\
0.39 \\
0.98 \\
0.59 \\
0.46 \\
0.04 \\
0.56 \\
0.52 \\
0.56 \\
0.59 \\
0.44 \\
0.85 \\
0.22 \\
0.40 \\
0.40 \\
0.86 \\
0 \\
0.41 \\
0.39 \\
0.19 \\
0.17 \\
0.32 \\
0.80 \\
0.39 \\
0.26\end{array}$ \\
\hline
\end{tabular}


Table 5 (continued)

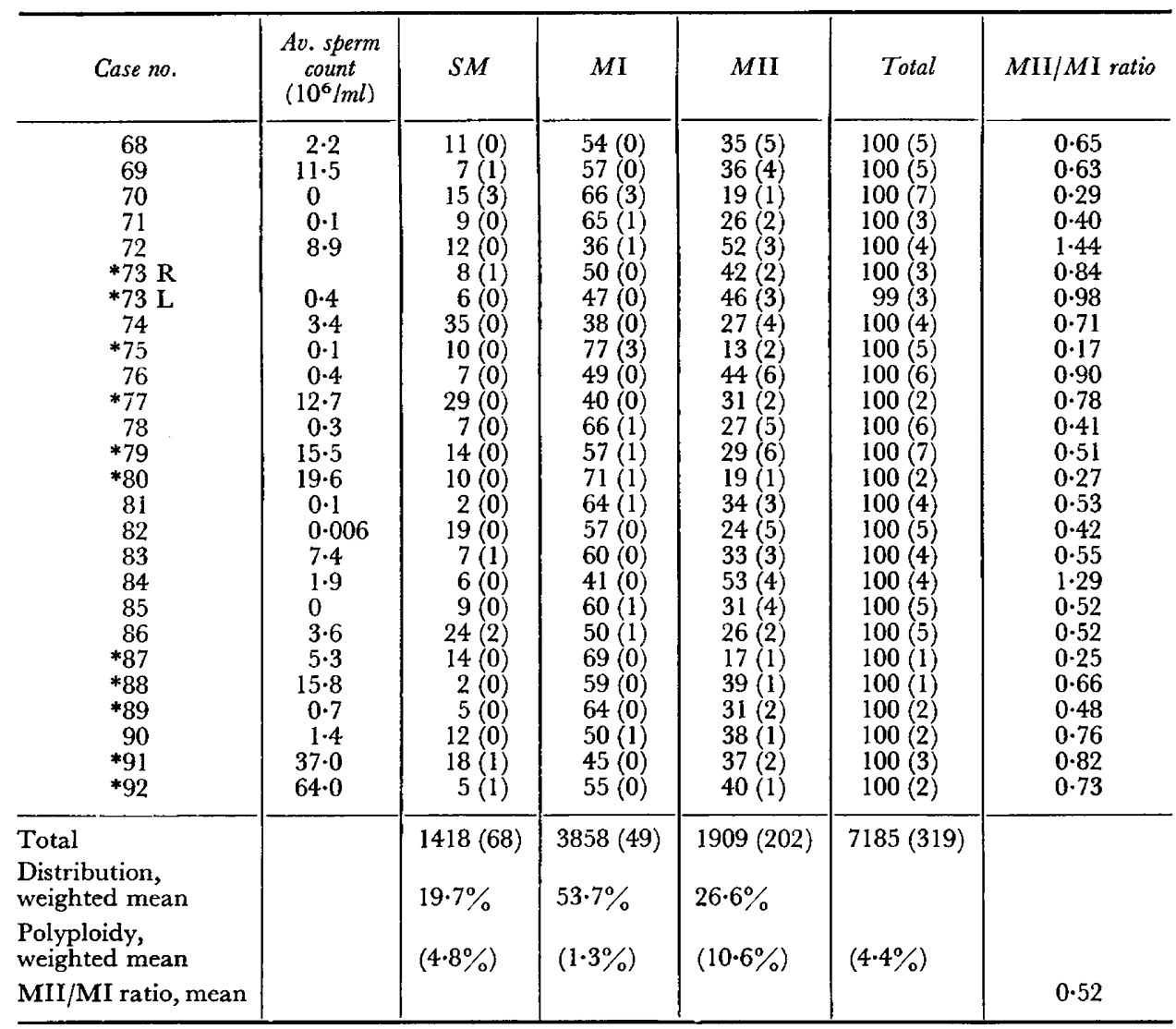

Figures in parentheses $=$ numbers of polyploid cells included in the counts. $R=$ right; $L=$ left.

* The histological sections of these men showed a homogenous picture with a quantitatively normal number of germ cells up to pachytene level but a reduced number of spermatids (N. E. Skakkebæk, R. Hammen, J. Philip and $\mathrm{H}$. Rebbe, unpublished observations).

As seen from Table 3, an almost total lack of cells in MII was found in Cases 22,48 and 59 .

A total of 667 cells in diakinesis from twenty-one patients was analysed in detail (Table 3). Forty-three $(6.4 \%)$ apparently aneuploid cells were found. One cell in diakinesis contained an extra bivalent and another had an extra small fragment (Pl. 4, Fig. 8). The remaining forty-one cells were apparently

Table 6. Analysis of variance of chiasma frequency in infertile males

\begin{tabular}{l|c|c|c|c}
\hline \multicolumn{1}{c|}{ Variation } & Sum of squares & Degrees of freedom & Variance & F-ratio \\
\hline Within individuals & $1169 \cdot 3$ & 102 & $11 \cdot 46$ & $5 \cdot 64^{*}$ \\
Between individuals & $970 \cdot 0$ & 15 & $64 \cdot 67$ & \\
\hline Total & $2139 \cdot 3$ & 117 & & \\
\hline
\end{tabular}

* Significant at the $1 \%$ level. 
lacking one or more bivalents and no obvious trivalent or tetravalent figures were seen. The sex chromosomes occurred as univalents in $15.0 \%$ of all cells with some variation between individuals. A pair of small autosomes was separated in a total of three cells in diakinesis (Pl. 5, Fig. 9).

Chiasma counts were performed on a total of 118 cells from sixteen individuals (Table 4). The average number of chiasmata varied between 42.5 and 55.0 with a mean of 48.7 for the group as a whole. By analysis of variance (Table 6), the difference in chiasma frequency between the infertile men was found to be significant $(P<0.01)$. The variation could not be correlated with any clinical traits of the patients nor with age. The difference in mean chiasma frequency between the fertile and infertile men was not significant $(P>0.05)$.

A small proportion ( 3 to $6 \%$ ) of cells in diakinesis from subjects Nos 32,59 and 66 had an abnormal appearance with indistinct and grossly fragmented chromosomes and extremely low chiasma frequency (Pl. 5, Fig. 10). No such cells were included in the chiasma count.

Polyploid cells were found in $4.8 \%$ of cells in spermatogonial metaphase, $1.3 \%$ of cells in diakinesis and $10.6 \%$ of cells in MII.

\section{DISCUSSION}

The present study mainly concerns (1) the distribution of cells in spermatogonial metaphase, MI and MII, (2) chiasma frequency in MI, (3) non-pairing of sex chromosomes and homologous chromosomes in MI, (4) polyploidy, and (5) a comparison of the above mentioned factors between the infertile men and the controls. No information on the occurrence of structural chromosome abnormalities was obtained.

\section{Distribution of cells in metaphase}

The ratio of 0.5 between cells in MII and MI (MII/MI ratio) in the infertile men is considerably lower than the mean of 0.9 in the controls. The MII/MI ratio is of interest because an impairment of spermatogenesis between the two meiotic divisions should be reflected through a decreased MII/MI ratio down to zero. The question may be raised whether arrest of spermatogenesis at spermatocyte level, which is seen in histological sections from some patients, is due to an inhibition before MI, between MI and MII, or after MII. Due to the lack of a substantial number of cells in metaphase and to great difficulties in distinguishing between $\mathrm{MI}$ and $\mathrm{MII}$ in histological preparations, an analysis of meiosis utilizing an air-drying technique may contribute information.

In Cases 22, 48, 59 and 82, spermatogenic arrest was found at the spermatocyte level on histological analysis (N. E. Skakkebæk, R. Hammen, J. Philip and $\mathrm{H}$. Rebbe, unpublished observations). There is now evidence that this arrest was almost total between MI and MII in three of these four cases (22, 48 and 59). McIlree, Price, Court Brown, Tulloch, Newsom \& Maclean (1966) reported three cases with an arrest between MI and MII. Similarly, Hultén, Eliasson \& Tillinger (1970) and Pearson, Ellis \& Evans (1970) found a total of three patients with arrest at the same level. On the other hand, spermatogenesis in Case 82 continued at least to the level of MII. In another study, we 
PLATE 1

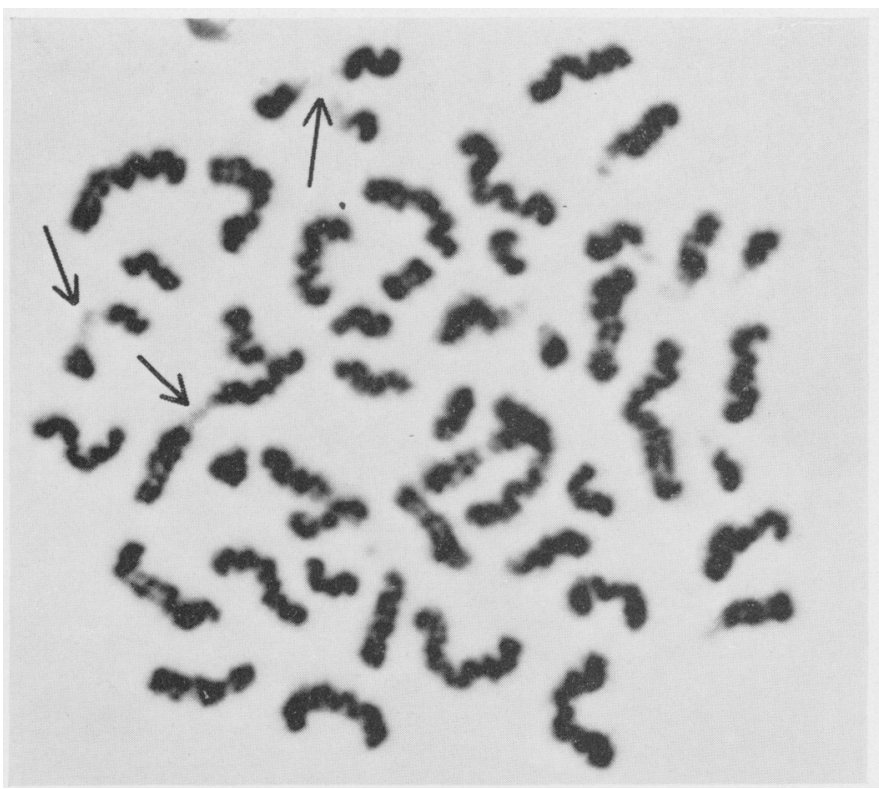

FIG. 1. Spermatogonial metaphase (control male). Note the secondary constrictions in three of the chromosomes (arrows).

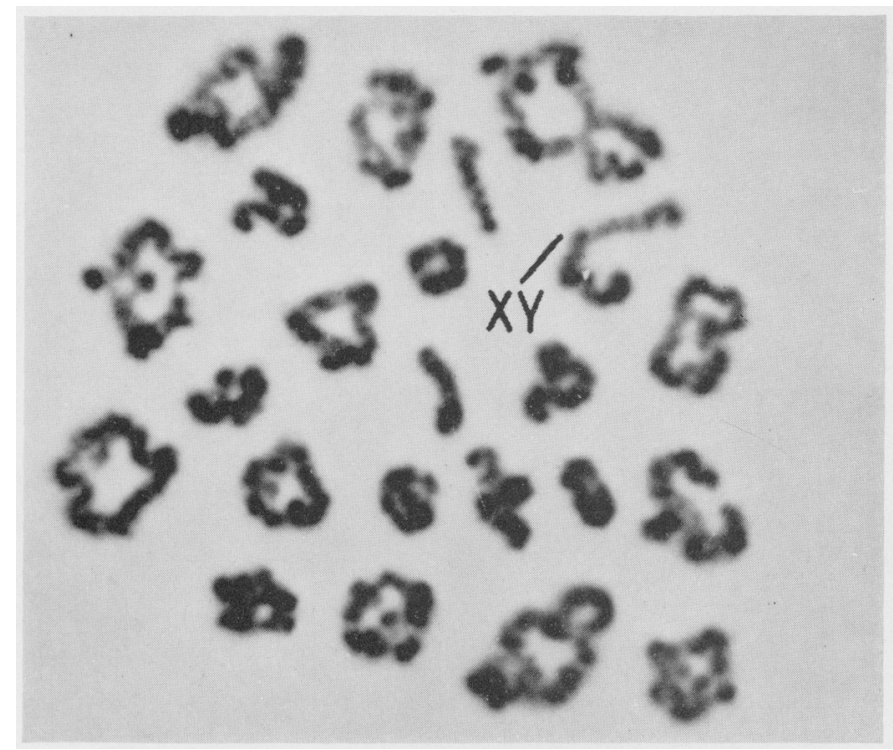

FIG. 2. A cell in diakinesis-metaphase I with 23 bivalents including an XY bivalent (control male). 
PLATE 2

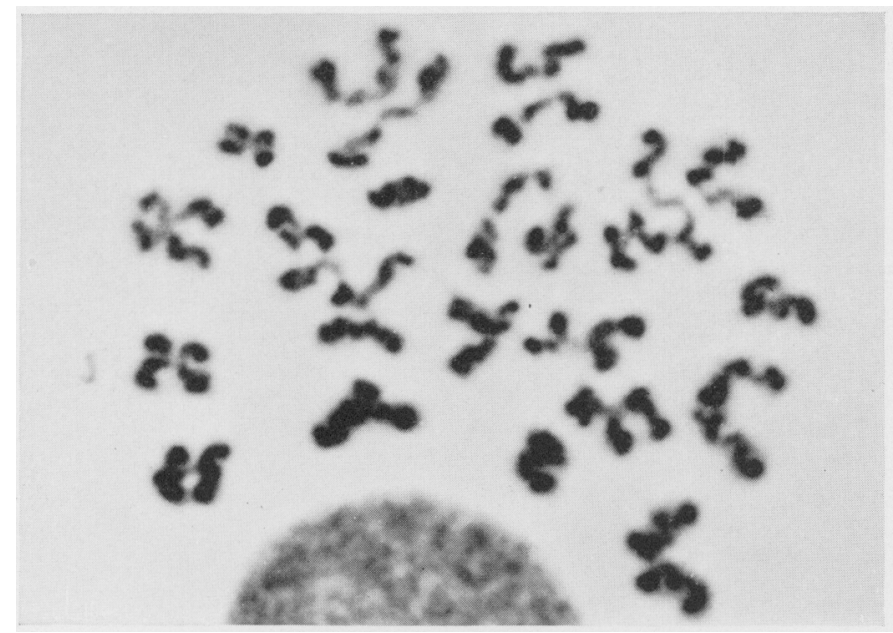

FIG. 3. A cell in metaphase II (control male).

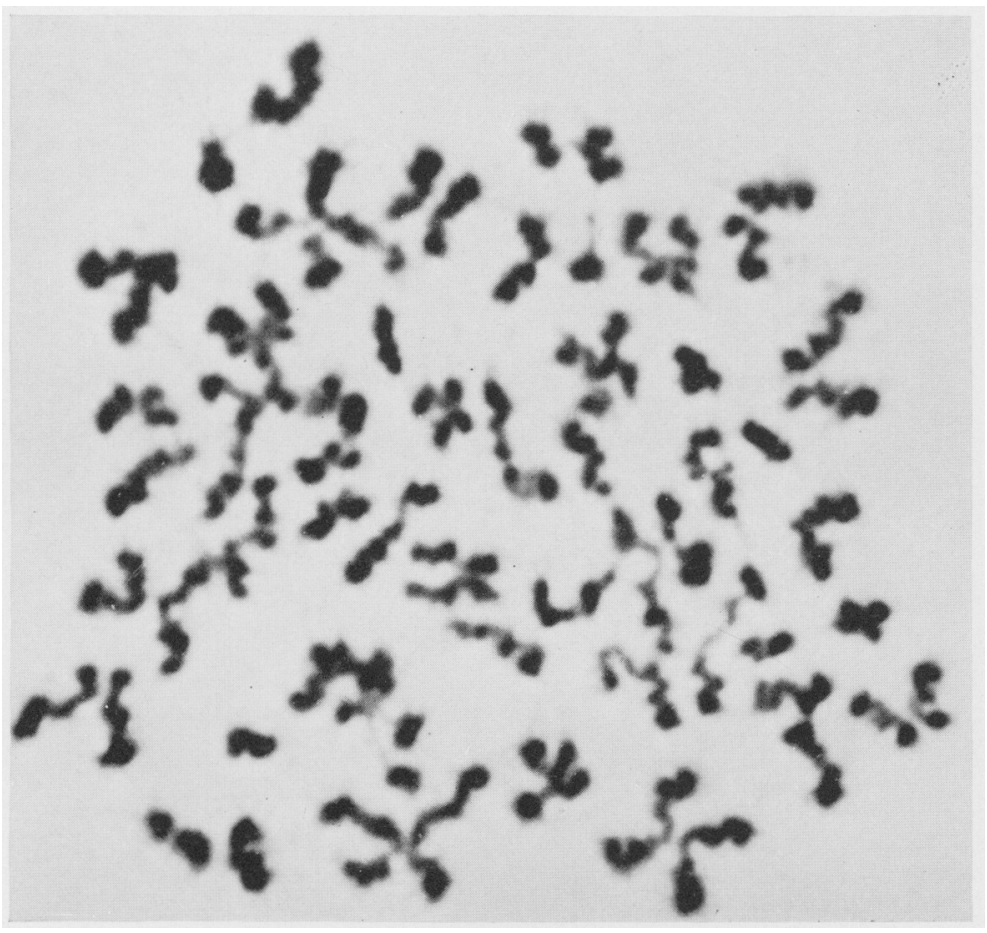

FIG. 4. A polyploid cell in metaphase II (control male). 


\section{PLATE 3}

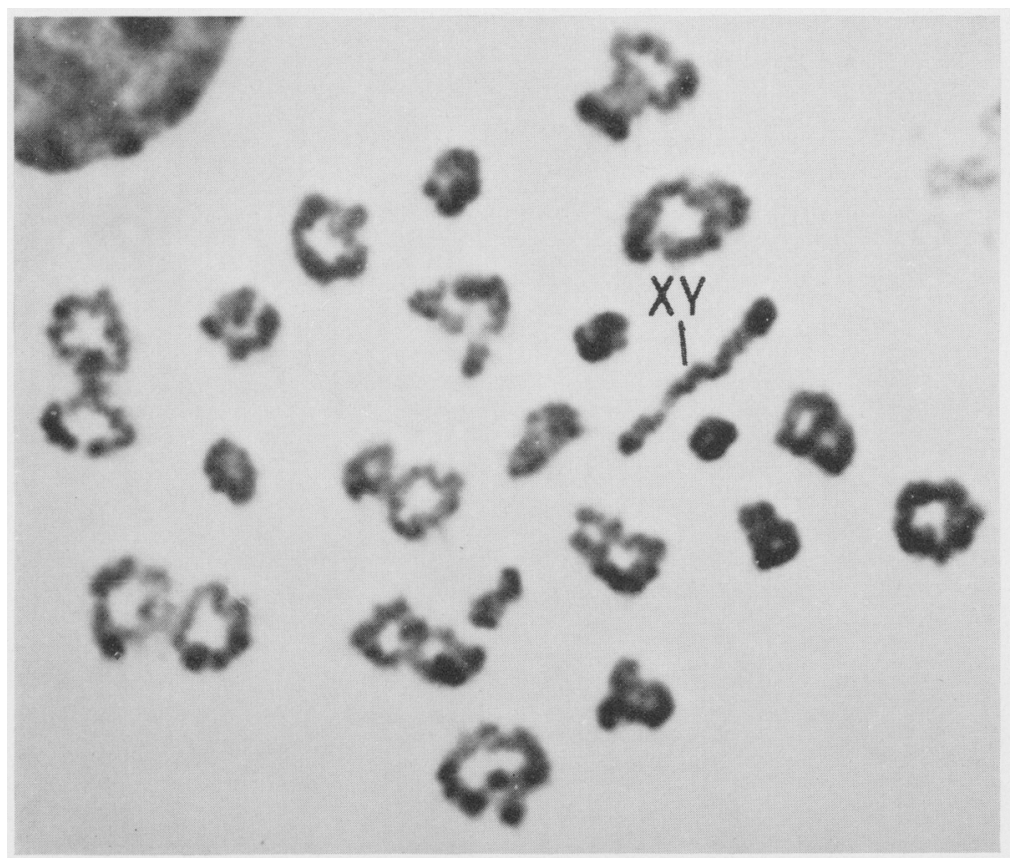

FiG. 5. A cell in diakinesis-metaphase $\mathrm{I}$, apparently containing 22 bivalents including an $\mathrm{XY}$ bivalent (control male).

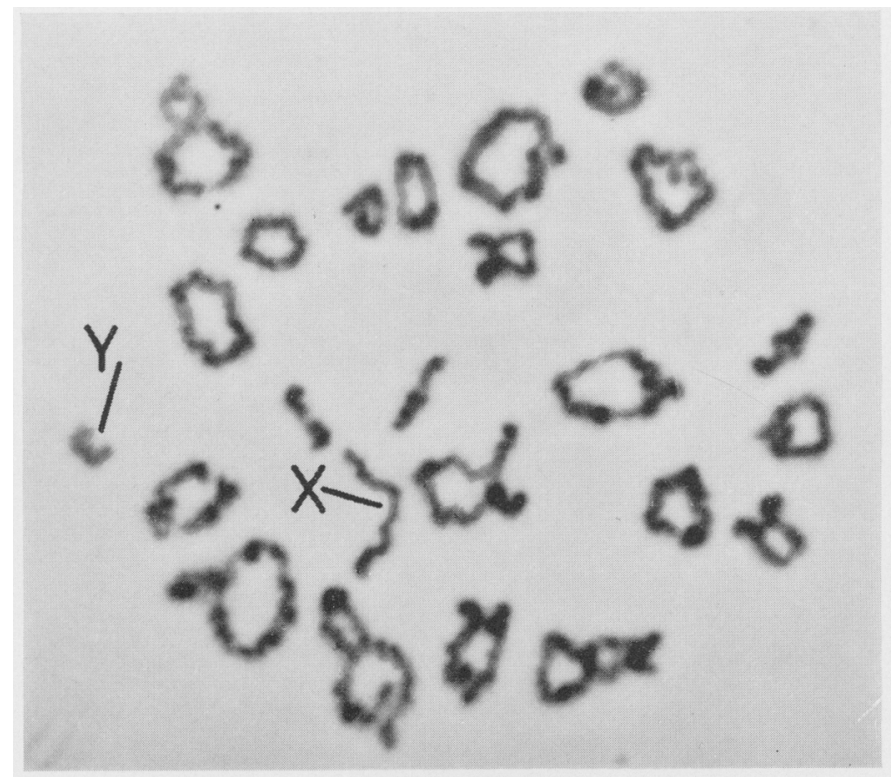

Fig. 6. A cell in diakinesis with the sex chromosomes separated (infertile male). 


\section{PLATE 4}

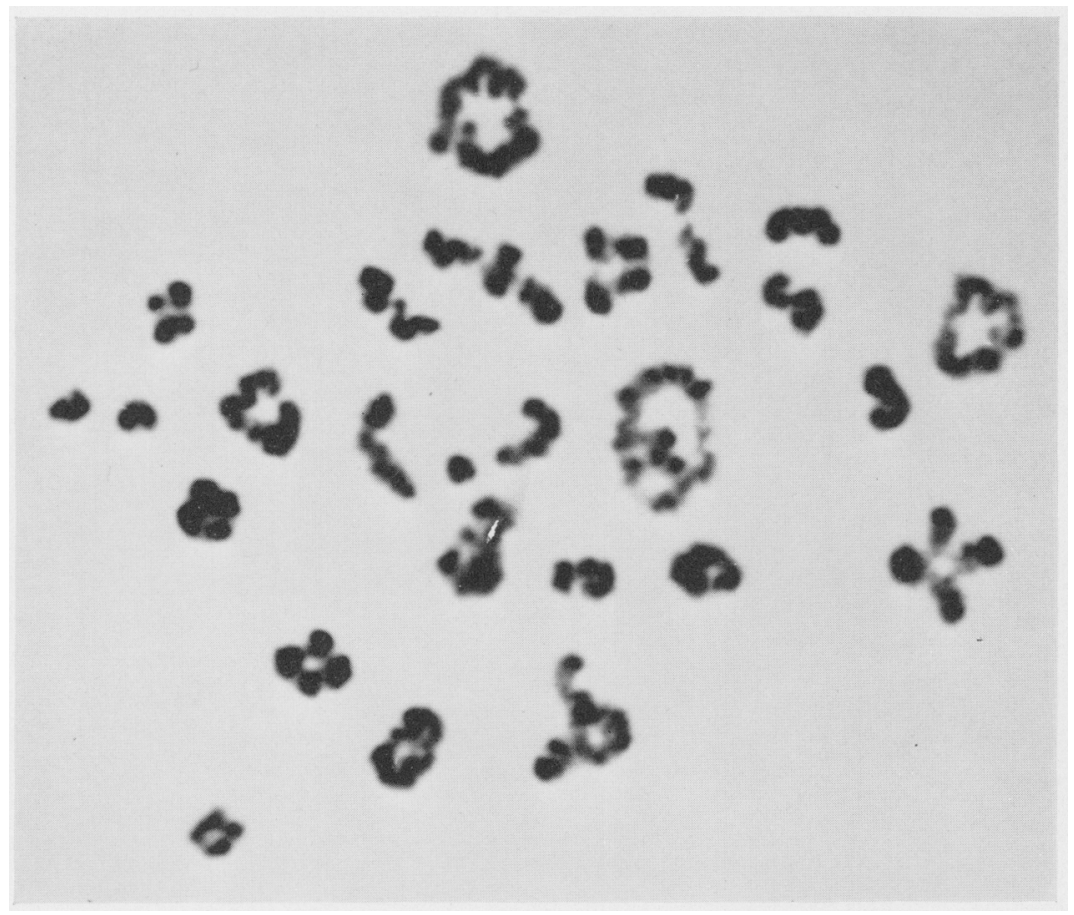

FIg. 7. A cell in diakinesis-metaphase I with extremely low chiasma frequency (control male).

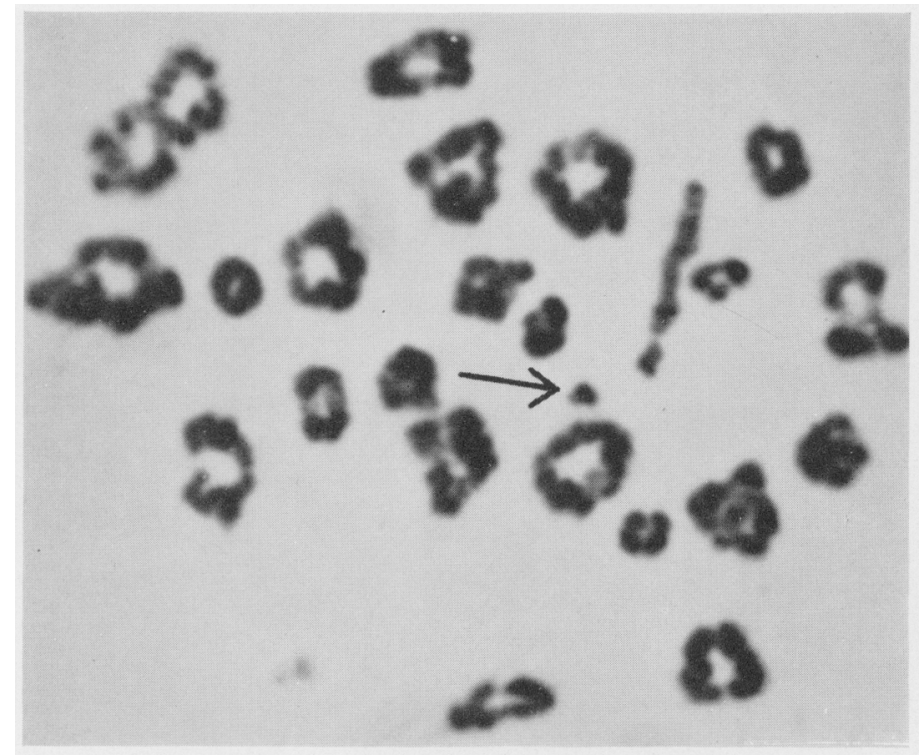

Fig. 8. A cell in diakinesis containing an extra small fragment indicated with an arrow (infertile male). 


\section{PLATE 5}

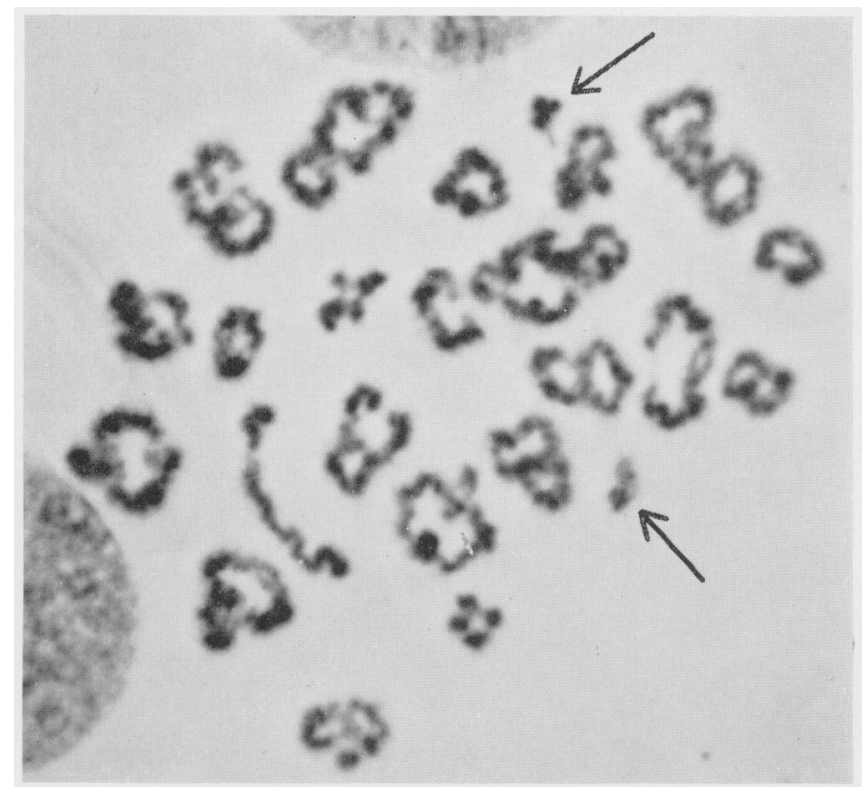

Fig. 9. A cell in diakinesis with two small homologous autosomes as univalents indicated with an arrow (infertile male).

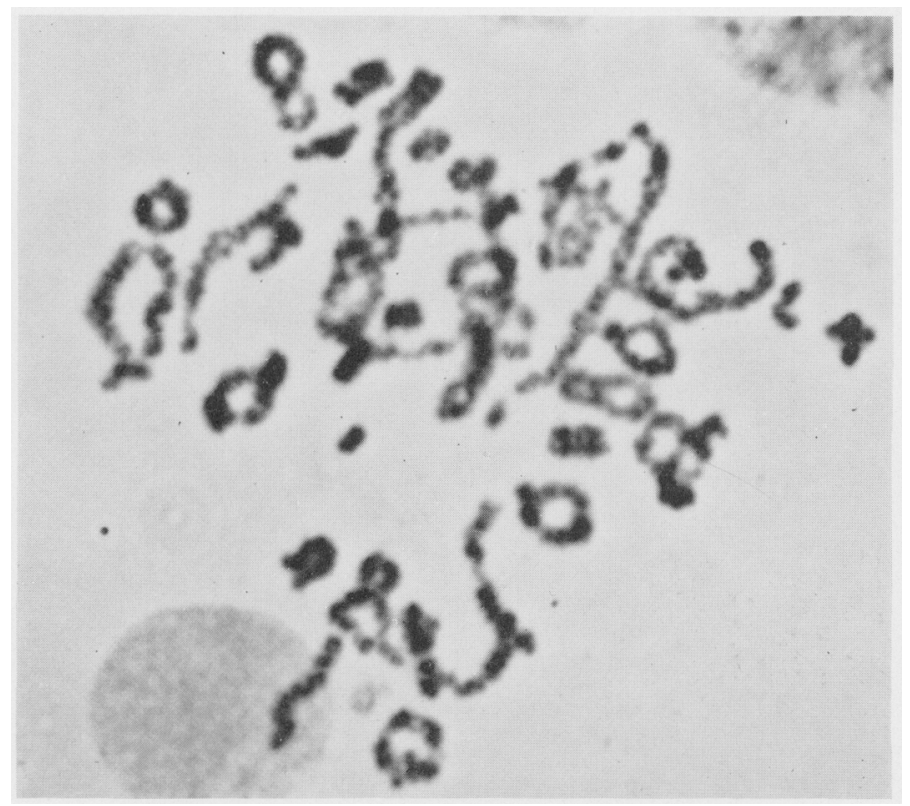

Fig. 10. A cell in diakinesis with indistinct and grossly fragmented chromosomes with extremely low chiasma frequency (infertile male). 
found a patient (an XYY male) with a similar histological picture but with an apparent arrest before metaphase I (Skakkebæk, Philip, Mikkelsen, Hammen, Nielsen, Perbell \& Yde, 1970). It therefore appears that the pathological condition, called spermatogenic arrest, does not constitute an entity.

The investigation also provided evidence that spermatogenesis may be impaired at the level of the meiotic divisions in patients with a partial reduction in the number of spermatids. We had previously found (N. E. Skakkebæk, R. Hammen, J. Philip and H. Rebbe, unpublished observations) that eighteen of the infertile patients (marked with * in Table 5) had a quantitatively normal number of germinal cells up to pachytene level but a reduced number of spermatids. As seen from Text-fig. 1, this group showed low MII/MI ratios compared with the fertile men.

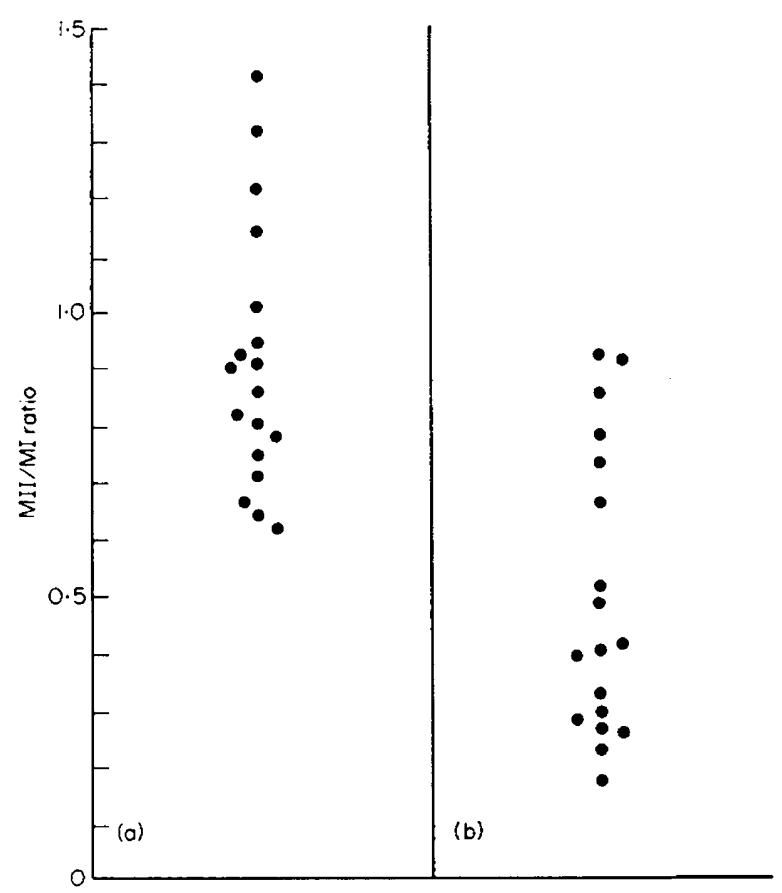

TexT-rig. 1. The MII/MI ratio of (b) eighteen men with reduced numbers of late spermatids (those marked with * in Table 5, compared with the corresponding values for the group of eighteen controls (a).

A comparison between analysis of meiotic chromosomes and histology is of minor interest in the remaining patients, some of whom already showed inhibition of spermatogenesis at the spermatogonia-early spermatocyte level or a heterogeneous appearance in histological section. In other cases, the histological part of the testicular biopsy was unsuitable for analysis of the germinal cells.

The relative number of spermatogonial metaphases was higher among the infertile men $(19 \cdot 7 \%)$ than among the controls $(9 \cdot 4 \%)$. This observation probably reflects the phenomenon that, in oligospermic males, the absolute 
number of spermatogonia is often normal in spite of a reduction in the number of spermatocytes.

\section{Chiasma frequency}

The average chiasma frequency of 51.2 found in our controls is in line with other studies on men with normal spermatogenesis (4th Int. Conf. on Standardization in Human Cytogenetics, 1971). The difference between the controls and the infertile men was not statistically significant, but the variation between the infertile men was significant. The importance of this variation remains to be determined. In three of the patients (Cases 32, 59 and 66), a small percentage of cells in diakinesis contained indistinct and grossly fragmented chromosomes with extremely low chiasma frequency similar to findings reported by Dutrillaux \& Guéguen (1971) in an oligospermic male. Low chiasma frequencies were found by Hultén, Eliasson \& Tillinger (1970) and Pearson et al. (1970) in all cells in diakinesis in their three patients mentioned above with spermatogenic arrest. Four cases of the present investigation (22, 48, 59 and 82) with spermatogenic arrest showed no such abnormalities except the previously mentioned Case 59 , in whom $5 \%$ of these cells had this appearance. No cells in diakinesis of Cases 22, 48 and 82 were suitable for exact counts; however, gross abnormalities such as those reported by Hultén, Eliasson \& Tillinger (1970) and Pearson et al. (1970) could be excluded.

\section{Non-pairing of the sex chromosomes and homologous chromosomes}

The most common deviation was a dissociation of $\mathrm{X}$ and $\mathrm{Y}$ which occurred in $15.0 \%$ of a total of 1159 cells studied. Small autosomes were separated in an occasional cell. No differences were noted between the fertile and infertile men.

The occurrence of the sex chromosomes as univalents has been reported by other investigators (Ford \& Hamerton, 1956; Sasaki \& Makino, 1965; Hultén, Lindsten, Ming \& Fraccaro, 1966; Kjessler, 1966; Eberle, 1966; Hultén, Lindsten, Lidberg \& Ekelund, 1968; Luciani, 1970a, b), who mainly studied material obtained from infertile men or patients with urological disorders. Autosomal univalents in a few cells were reported by Luciani (1970a, b) in a single study of men with apparently normal testicular histology. Some of these findings may be artefacts due to handling and preparation, as suggested by Ford \& Evans (1964) who discussed the dissociation of sex chromosomes in mice. However, the fact that different investigators using different techniques on human material all found a proportion of cells with the $\mathrm{X}$ and $\mathrm{Y}$ separated indicates that the dissociation probably reflects a real phenomenon, which may be due to either failure of pairing in zygotene or precocious separation. The latter was suggested by Hultén, Lindsten, Ming \& Fraccaro (1966). We also found that a dissociation of $\mathrm{X}$ and $\mathrm{Y}$ tended to occur in cells towards the later stages of metaphase $I$ and we believe that the phenomenon is due to precocious separation.

Non-pairing of homologous chromosomes at metaphase I may lead to nondisjunction and the production of aneuploid spermatozoa. The abnormalities that we have observed here could give rise to zygotes with the chromosomal complements of $47, \mathrm{XXY}, 45, \mathrm{X}$ and possibly also to $47, \mathrm{XY},+21$. It is interesting 
that these are three common chromosomal syndromes, i.e. Klinefelter's, Turner's and Down's syndromes. Race \& Sanger (1969) estimated that the extra X chromosome in Klinefelter's syndrome is of paternal origin in approximately $40 \%$ of the cases. Such cases arose from non-disjunction of the sex chromosomes during the first male meiotic division. Race (1965) estimates $76 \%$ of individuals with non-mosaic XO Turner's Syndrome are due to loss of a paternal $\mathrm{X}$ or $\mathrm{Y}$ chromosome. The most common autosomal trisomy, $\mathrm{G}$ trisomy, theoretically may originate from non-disjunction during male meiosis as well as from maternal non-disjunction. Paternal secondary non-disjunction of $\mathrm{G}$ chromosomes has been established (Hsu, Gertner, Leiter \& Hirschhorn, 1971). Therefore, mature spermatozoa carrying an extra $G$ chromosome can be functional.

\section{Polyploid cells}

The percentage of polyploid cells in diakinesis as well as spermatogonial metaphase and MII was low compared with previous investigations (Sasaki \& Makino, 1965; McIlree, Tulloch \& Newsam, 1966; Luciani, 1970a, b). However, most of the previous information on polyploidy appears to have been obtained from studies on men with urological or testicular disorders. We found a higher frequency of these cells in the infertile men, but only in MII.

In mice and other mammalian species, such polyploid cells are also present (Hultén, Karlman, Lindsten \& Tiepolo, 1970). They may result from cell fusion or be truly polyploid cells formed by endoreplication as discussed by Hultén, Karlman, Lindsten \& Tiepolo (1970) and Ford \& Evans (1971). The chromosomes of polyploid primary spermatocytes of the Chinese hamster were found to replicate DNA simultaneously (Hultén, Karlman, Lindsten \& Tiepolo, 1970). On the other hand, studies in mice with a reciprocal translocation gave no evidence of formation of truly polyploid primary spermatocytes (Ford \& Evans, 1971). Presumed diploid spermatozoa have been found in animals as well as in man (Beatty, 1961; Gledhill, 1964; Salisbury \& Baker, 1966; Sumner, Robinson \& Evans, 1971; Sumner, 1971), although it is not known if diploid spermatozoa are able to fertilize. The extra sets of chromosomes in the karyotypes of polyploid spontaneous abortions may be of either paternal or maternal origin (Carr, 1967; Uchida \& Lin, 1972). However, cases with diandry may well have originated from the entry of two spermatozoa into the egg, although the possibility that a diploid spermatozoon may enter an ovum, as indicated by McIlree, Tulloch \& Newsam (1966) and Sumner (1971) must be considered.

The finding of a significantly increased number of polyploid (most often diploid) cells in MII of infertile men is of some clinical interest, although these men only occasionally father offspring. It remains, however, to be seen if triploid embryos are more likely to occur in these rare instances.

\section{Structural chromosome aberrations}

In a study of meiotic chromosomes of aspermic and oligospermic men, McIlree, Price, Court Brown, Tulloch, Newsam \& Maclean (1966) found two patients with structural chromosome aberrations which could not be revealed 
by chromosome analysis of peripheral blood. On the other hand, Kjessler (1966), in a similar study, did not report any such cases.

Apparent aneuploidy was found in a small percentage of the cells in $\mathrm{MI}$ in both the controls and the infertile men. Such cells have probably lost one or more bivalents during preparation because none of them contained obvious multivalent figures. However, it cannot be entirely excluded that some of the apparently aneuploid cells do, in fact, contain multivalent figures due to structural aberrations (Hultén et al., 1968).

A study of the banding patterns of chromosomes made possible by recent advances in staining techniques may provide a more reliable method for distinguishing between aneuploid cells and cells containing chromosomes with structural aberrations (Caspersson, Hultén, Lindsten \& Zech, 1971; 4th Int. Conf. on Standardization in Human Cytogenetics, 1971).

\section{Fragments}

A single cell with an extra fragment was found in one of the patients. Supposing that a cell of this type may develop through meiosis and spermiogenesis, it may be the source of an extra fragment in the karyotype of the offspring. Several individuals with an extra fragment in the karyotype have been reported (cf. Nielsen, Friedrich, Tsuboi \& Dalby, 1971) and it has been shown that they may be able to transmit the extra fragment through meiosis (Hultén, Lindsten, Fraccaro, Mannini \& Tiepolo, 1966; J. Nielsen and N. E. Skakkebæk, unpublished observations).

It was concluded that the chiasma frequency, the non-pairing of sex chromosomes and homologous chromosomes and the occurrence of polyploid cells in MI were the same in the controls and the infertile men. The differences between the two groups were a small proportion of cells in MI with distinct and grossly fragmented chromosomes together with low chiasma frequency in three infertile men, an increased number of polyploid cells in MII, and a reduced MII/ MI ratio in the group of infertile men as a whole.

Although no primary structural abnormalities were recorded by the meiotic analysis of these infertile men, the investigation was a valuable supplement to the histological analysis of patients with spermatogenic arrest.

\section{AGKNOWLEDGMENTS}

We are grateful to Dr H. Rebbe for testicular biopsies, and to Dr R. Hammen for sperm analysis. This work was supported by the P. Carl Petersen Fund, the Danish Medical Research Council and U.S. Public Health Service grant GM 15253 from the National Institutes of Health. The first author held a scholarship from the University of Copenhagen during his stay in the U.S.A.

All the control-group volunteers participated in a hormone research programme in Oregon State Penitentiary under the direction of Dr Carl C. Heller, who generously made this study possible by providing us with testicular material.

\section{REFERENCES}

BEATTY, R. A. (1961) Genetics of gametes. V. The frequency distribution of the head length of rabbit spermatozoa, and a search for dimorphism. Proc. R. Soc. Edinb. B, 68, 72. 
CARr, D. H. (1967) Chromosome anomalies as a cause of spontaneous abortion. Am. F. Obstet. Gynec. $97,283$.

Caspersson, T., Hultén, M., Lindsten, J. \& Zech, L. (1971) Identification of chromosome bivalents in human male meiosis by quinacrine mustard fuorescence analysis. Hereditas, 67, 147.

Dutrillaux, B. \& GUÉGuen, J. (1971) Multiple meiotic and gametic anomalies in a case of sterility in the male. Annls Génét. 14, 49.

Eiberle, P. (1966) Die Chromosomenstruktur des Menschen in Mitosis und Meiosis. Gustav Fischer, Jena.

Evans, E. P., Breckon, G. \& Ford, C. E. (1964) An air drying method for meiotic preparation from mammalian testes. Cytogenetics, 3, 289.

Ford, C. E. \& Evans, E. P. (1964) A reciprocal translocation in the mouse between the $\mathrm{X}$ chromosome and a short autosome. Cytogenetics, 3, 295.

Ford, C. E. \& Evans, E. P. (1971) Origin of apparent polyploid spermatocytes in the mouse. Nature, Lond. 230, 389.

Ford, G. E. \& Hamerton, J. L. (1956) The chromosomes of man. Nature, Lond. 178, 1020.

GleDHILL, R. L. (1964) Quantitative ultramicrospectrophotometry of presumed diploid bovine spermatozoa. 5th Int. Congr. Anim. Reprod. EO A. I. 3, 489.

HAMmEN, R. (1944) Impaired fertility in man. With special reference to the male. Munksgaard, Copenhagen and London.

Hsu, L. Y. F., Gertner, M., Lemer, E. \& Hrrschhorn, K. (1971) Paternal trisomy 21 mosaicism and Downs syndrome. Am. F. hum. Genet. 23, 592.

Hultén, M., Eliasson, R. \& Tillinger, K. G. (1970) Low chiasma count and other meiotic irregularities in two infertile 46,XY men with spermatogenic arrest. Hereditas, 65, 285.

Hultén, M., Karlman, A., Lindsten, J. \& Tiepolo, L. (1970) Aneuploidy and polyploidy in germline cells of the male Chinese hamster. Hereditas, 65, 197.

Hultén, M., Lindsten, J., Fraccaro, M., Mannini, A. \& Tiepolo, L. (1966) Extra minute chromosome in somatic and germ-line cells of the same person. Lancet, ii, 22.

Hultén, M., Lindsten, J., Lidberg, L. \& Ekelund, H. (1968) Studies on mitotic and meiotic chromosomes in subjects exposed to LSD. Annls Génét. 11, 201.

Hultén, M., Lindsten, J., Ming, P.-M. L. \& Fraccaro, M. (1966) The XY bivalent in human male meiosis. Ann. hum. Genet. 30, 119.

4th Int. Conf. on Standardization in Human Cytogenetics, Parts (1971) The National Foundation, March of Dimes, New York.

KJEsSLER, B. (1966) Karyotype, meiosis and spermatogenesis in a sample of men attending an infertility clinic. Karger, Basel.

Luciani, J. M. (1970a) Les chromosomes méiotiques de l'homme. I. La méiose normale. Annls Génét. $13,101$.

Lucrani, J. M. (1970b) Les chromosomes méiotiques de l'homme. II. Le nucléole. Les chiasmas. III. La stérilité masculine. Annls Génét. 13, 169.

McIlree, M. E., Price, W. H., Court Brown, W. M., Tulloch, W. S., Newsam, J. E. \& Maclean, N. (1966) Chromosome studies on testicular cells from 50 subfertile men. Lancet, ii, 69.

MaIlree, M. E., Tulzoch, W. S. \& Newsam, J. E. (1966) Studies on human meiotic chromosomes from testicular tissue. Lancet, i, 679.

Nielsen, J., Friedrich, U., Tsubor, T. \& Dalby, A. (1971) Father and son with karyotype 47,XY,Yq-. Hum. Genet. 11, 247.

Pearson, P. L., Ellis, J. D. \& Evans, H. J. (1970) A gross reduction in chiasma formation during meiotic prophase and a defective DNA repair mechanism associated with a case of human male infertility. Cytogenetics, 9, 460.

Philip, J., Skakkebek, N. E., Hammen, R., Johnsen, S. G. \& Rebbe, H. (1970) Cytogenetic investigations in male infertility. Acta obstet. gynec. scand. 49, 235.

RACE, R. R. (1965) Identification of the origin of the $\mathrm{X}$ chromosomes in sex chromosome aneuploidy. Can. F. Genet. Cytol. 7, 214.

RAce, R. R. \& SANGER, R. (1969) Xg and sex chromosome abnormalities. Br. med. Bull. 25, 99.

SALISBURY, G. W. \& BAKER, F. N. (1966) Frequency of occurrence of diploid bovine spermatozoa. F. Reprod. Fert. 11, 477.

Sasaki, M. \& Makino, S. (1965) The meiotic chromosomes of man. Chromosoma, 16, 637.

SKAKKEB BE, N. E. \& HeLleR, C. G. (1973) Quantification of human seminiferous epithelium. I. Histological studies in twenty-one fertile men with normal chromosome complements. $\mathcal{F}$. Reprod. Fert. 32, 379.

Skakkebak, N. E., Philip, J., Mikkelsen, M., Hammen, R., Nielsen, J., Perbøll, O. \& Yde, H. (1970) Studies on spermatogenesis, meiotic chromosomes and sperm morphology in two males with a 47, XYY chromosome complements. Fert. Steril. 21, 645.

Sumner, A. T. (1971) Frequency of polyploid spermatozoa in man. Nature, Lond. 231, 49. 
Sumner, A. T., Robinson, J. A. \& Evans, H. J. (1971) Distinguishing between XY and YY-bearing human spermatozoa by fluorescence and DNA content. Nature, Lond. New Biol. 229, 231.

UchidA, I. A. \& LIN, G. C. (1972) Identification of triploid genome by fluorescence microscopy. Science, N.Y. 176, 304. 